\title{
バスケットボールの創成
}

水谷 豊

\section{The dawn of the game of basketball}

\author{
Yutaka Mizutani
}

\begin{abstract}
It is well known that the game of basketball was created by James Naismith at the International YMCA Training School (now Springfield College) in Springfield, MA, USA, and that the first game was played on December 21, 1891. Since then, the game has gained wide popularity in the USA, despite the fact that for a time it was denounced as an activity that ran counter to "YMCA philosophy". This essay attempts to trace the very beginnings of the game and to identify the major factors responsible for its growth into a top global sport. It can be concluded that (1) Naismith's original concept for the game of basketball has indeed lived up to its "unfailing potentiality" for development as an enjoyable sport. (2) The YMCA made a leading contribution to the cultivation of physical education at that time, and to the rapid popularization of the game through their network in the USA. (3) The social and cultural changes in the last two decades of the 19th century in the USA led to an awakening of a new era of physical education and sport. Thus the game of basketball, originally designed to be played as an indoor ball game during the winter season to sublimate students' "play instincts" at the International YMCA Training School at that time, finally grew to become a global sport.
\end{abstract}

\section{Key words : new game, James Naismith, YMCA}

(Japan J. Phys. Educ. Hlth. Sport Sci. 50: 249-258, May, 2005)

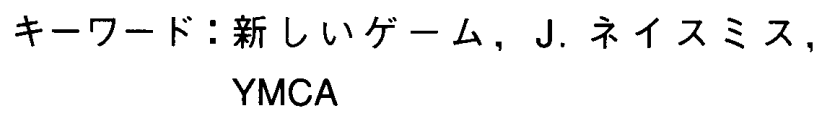

\section{はじめに}

バスケットボールが誕生したのは 1891 年のこ とだが，その 5 年後の第 1 回近代オリンピック
（1896年・アテネ大会）から直ちにプレイされた わけではない. 公式競技種目になったのは男子が 1936 年（第 11 回・ベルリン大会），女子が 1976 年（第 21 回・モントリオール大会）である。“創 始国”アメリカは男子が 1936 年一1968年（第 19 回・メキシコシティ大会）の間, 制覇し続けた. そして，1972年（第 20 回・ミュンヘン大会）に
日本バスケットボール協会

干 150-8050 東京都渋谷区神南 1-1-1

連絡先 水谷 豊
Japan Basketball Association

1-1-1, Jinnan, Shibuya-ku, Tokyo, Japan 150-8050

Correspondingauthoryutaka.m@guitar.ocn.ne.jp 
当時のソ連に苦杯を喫して, 初めて王座から陥落 した．だが，間髪を容れず，1976年（第 21 回・ モントリオール大会）に金メダルを奪回し，その 後は 2000 年（第 27 回・シドニー大会）まで再び 君臨し続けた。この経過のなかでアメリカが 1992 年（第 25 回・バルセロナ大会）に初めてプ ロのNBA（National Basketball Association） プ レイヤーで編成したチームで出場した。アメリカ のゲームはことごとくテレビ放映され，もっとも 新しい洗練されたプレイが一気に地球の隅々まで 駆け巡った。これが誘因となり，世界各国に大き なレベルアップをもたらした。 なかでもヨーロッ パ地区のそれは目覚ましく，男女プロリーグの振 興につながった。やがて，優秀なプレイヤーの $\mathrm{NBA}$ への流入が年ごとに増加し始め，逆に “NBA 洩れ”したアメリカの優れたプレイヤーの ヨーロッパ地区への流出も常態化した.アメリカ では 2000 年以降，NBA を模したかごとくの女子 プロリーグ（WNBA：Women's National Basketball Association）が発足し，この定着に伴っ て男子と同様に主にヨーロッパ地区とのプレイヤ 一の流出・流入が年を追うごとに増加している.

このような国際バスケットボール情勢の影響は まず男子に生じた. 1992年のオリンピック・バ ルセロナ大会では「勝敗は度外視．NBAチーム と正規の手合わせができるだけで十分」とばかり， ゲーム開始前に対戦チームがにこやかにNBA ス タープレイヤーと記念写真を撮る有り様であっ た。ところが，ヨーロッパ各国から NBAに来て いる“出稼ぎプレイヤー”はオリンピックと世界 選手権大会では帰国し，「本国チームのプレイヤ 一」に変わる. 当然, アメリカとのチーム力は拮 抗し始める．2002年に開催された世界選手権大 会（於・インディアナ州インディアナポリス）で は遂に予想外の第6位となり，アメリカの “不敗 神話”が潰えたのはまだ記憶に新しい。

けれども，国際バスケットボール界におけるオ リンピックや世界選手権大会の覇者にいかなる変 化が生じようとも，バスケットボールの母国アメ リカがこれからも世界の冠たる“バスケットボー ル王国”であり続けることは必定であろう。それ
はNBA におけるプレイヤーの “グローバライゼ ーション”一アメリカから他国への流出と他国か らアメリカへの流入一は今日ほぼ5大陸ずへてに 及んでいるからである。

そこで，本稿ではいま一度アメリカに抄けるバ スケットボールの誕生およびその初期に遡及し, そこにまつわることに着目して若干の考察を試み ながら，近代スポーツの一つとして確立したバス ケットボールの「創成」の検証としてまとめるこ ととする。

\section{I バスケットボールの誕生}

1891 年 12 月 21 日，アメリカ・マサチューセッ ツ州スプリングフィールドの国際 YMCA トレー ニングスクールー。 インストラクターのJ. ネイ スミス（James Naismith）は創案に呻吟するこ と数日間，徹夜明计のこの日の朝，とうとう ‘頭 上の水平面のゴールにボールをショットし合う形 式の新しいゲーム’を描き終えた。 そして，ルー ルを作成した，意外なことに，それはわずか 13 条のみであった。しかし，その多くは今日なお底 流に脈々と生き続けている．まず，それを検証す ることによってバスケットボールの原点を概観し てみる（水谷, $1980 ；$ Wolff, 2002).

第1条 ボールはサッカーのボールを使用し， 片手あるいは両手で，どの方向にパスしてもよ い.

サッカーとアメリカンフットボールのボールが ネイスミスの目に留まった。「アメリカンフット ボールではボールを保持したプレイヤーの移動が 認められているので，持ちやすいように楕円形に なっているのだろう。しかし，この“新しいゲー ム’ではくボール保持者の移動＞を禁ずるのだか ら，楕円形でなくても困ることはない…と考え， 円形のサッカーボールを使うことにした. 1894 年にスプリングフィールドからそう遠くないチコ ピーフォールズという町にあった自転車製造会社 (オーバーマン・ホイール社）が初めて専用球を 売り出した。これが契機となって, 専用球の開発, 製造販売が始まった。 
第2条 ボールは片手，あるいは両手でどの方 向にたたいてもよい.ただし, 拳 (こぶし) でた たくのは禁止する.

ネイスミスは「狭い体育館で抒こなうゲームだ からラフプレイにつながる “芽”を極力つみ取っ ておく必要がある」と考えた. 拳の使用は危険と 判断したので，このように定めた.

第3条 ボールを保持したまま位置を変えるこ とを禁ずる. ボールをキャッチした地点に踏みと どまり，そこからパスしなければならない，かな リのスピードで走っているときにボールをキャッ チしたときは，もしストップしょうと努カしてい れば, 1-2歩は許されることもある.

国際 YMCA トレーニングスクールの “体育館” はどちらかと言うと “体育室”に近い屋内運動場 であり，およそ $11 \mathrm{~m} \times 13 \mathrm{~m}$ 程度のフロア面積で, ゲーム中にボールを保持したまま走り回ることが できるような広さではなかった。

ネイスミスは「・新しいゲーム’でアメリカン フットボールのようにボール保持者に対してタッ クリングすることを許せば，それはまさに“捨て 身の危険行為”となる，アメリカンフットボール ではボールを保持して思うままに位置を変えるこ とを許しているから，それを阻止するためにタッ クリングが必要となる. しかし, 逆にボール保持 者が位置を変えることを禁ずれば，ボール保持者 は必然的に“その地点”から移動できないことに なる．そうすれば，おのずからタックリングも不 要になる」と考えた。つまり，ボール保持者の不 正行動（ボールを保持した位置から他の位置への 移動）に厳しい規制を設けたことになる。これが 今日いう『トラベリング』(Traveling) に結びつ いた。 さらに，(ネイスミスはまったく予想たにに していなかったことだが）激しく迫って来るデ イフェンスにボールを奪回されまいと, ボール保 持者がコンパスの針のように片足を（その地点か ら動かさずに）定点とし，もう片方の足を踏み出 し，踏み変える動作を連続することによってボー ルをキープする『ピボッティング』(Pivoting) が生み出されてきた。しかし，ボール保持者は ‘その地点”から移動できないことには変わりな
い. 当然，ボール保持者はもはや“袋の鼠”も同 然である.ディフェンスはいっそう激しく執拗に 食い下がってくる，とうとう，ボール保持者はと っさの “窮余の一策”とばかり，ディフェンスか ら遠い方向にボールを軽く弾ませ，ボールが空中 にある間に ‘その地点’を離れ，急いでボールを 追いかけ保持し直すことによって一瞬ではある が，ディフェンスから逃れることができた。結果 的に，これを繰り返せば，ボールを保持したまま 位置を変えたことにはならないので，ルールに抵 触しない “異なる位置への移動手段”として『ド リブリング』（Dribbling）が生み出された。

第4条 ボールは両手で保持しなければならな い. 両腕や，からだを用いてはならない.

ネイスミスはもともとサッカーやアメリカンフ ットボールとは“ひと味異なる”ゲームを思い描 いていたので，プレイヤーがボールを蹴ったり， 小脇に隠すように抱えて走ることは想定していな かった。

第5条 どのような方法であれ，相手を小突い たり，つかまえたり，押したり，つまずかせたり， たたいたりすることは許されない.この規則の第 1 回目の違反は 1 個のファウルとする. 2 回違反 を犯した場合はつぎのゴールが成功するまで退場 とする.もし，故意に相手を傷つけようとするよ うなプレイであると見なされた場合はゲーム終了 後まで退場とする. この場合の交代プレイヤーの 出場は認めない.

いかなる暴力的行為も，あるいはラフプレイも 徽底的に排除しようというネイスミスの並々なら 断固たる気持ちが表われている。 それを『ファ ウル』と称し，その種類を明示した。また，ゲー ムが“荒れる”のを防ぐために「罰と代償」の考 え方も明示している。

第 6 条 第 2 -5 条で述べたことに 1 回違反を 犯すごとに, 1 個のファウルとする.

このルールでは今日いう「ファウル」も「バイ レーション」も十把一からげになっている，その 後,『フリースロー』(1点) が導入されて,「代 償」が明確になった。

第7条 両チームのどちらかが連続して3個の 
ファウルを犯すと，その相手チームに1ゴールを 与える. 連続とはその間に相手チームがひとつも ファウルをしない場合とする.

これが「代償」の具体策としての“ボーナス得 点”の考え方の基になった。

第8条 ボールが投げられるか，あるいは，た たかれてショットされ，バスケット内に入れば, ゴール成功である.もし，ボールがバスケットの 縁に止まったり，また，ショットしたときに相手 がバスケットを動かしたりした場合も，ゴール成 功とみなされる.

当初のバスケットは底が付いた “籠”が用いら れたので，ショットが成功すると，ボールは当然 ながら籠の中に残っている，そこで，立てかけた 梯子を使ってボールを回収するか，2階のバルコ ニーに上がってボールを籠から取り出していた. これでは非常に不便だし，ゲームの流れも止まっ てしまい面白くない。これを解消すべく，1906 年から「底」を取り払い，ボールが “通過”する ようにルールを変更した。

また，当時，バスケットは 2 階で立ち見してい る観衆のすぐ足元に取り付けられていたので，成 功しそうなショットのボールを足や手で妨害する ことがあった。 そこで，バスケットの真後ろの部 分に木板や金網を張り，妨害されるのを避けた。 そこから，『バックボード』が生まれた。

第9条 ボールがコート外に出た場合は最初に コート外のボールを保持したプレイヤーがコート 内にスローインする. そのとき，スローアーは 5 秒間だけ相手チームから妨害されないで, ボール を保持することを許される.もし，どちらのチー ムのボールとなるか判定がつかないときは副審が そこからまっすぐ投げ入れる．スローインのさい に5秒間を超えると，ボールは相手側に与えられ る.もし，スローインのとき，どちらかのチーム がゲームの再開を遅らせようとした場合は副審が そのチームにファウルを宣告する.

言うならば “早い者勝ち”である，当然，凄ま じいまでのボール争奪戦がコート外で繰り広げら れた。 ネイスミスは「私が教えていた初期のチー ムではコート外に出たボールを真っ先に確保しょ
うとボールめがけて殺到し，その勢いの余り，暖 房器の角にぶつかってできた “傷”を自慢げに見 せ合うのを楽しんでいる者がいた」と述懐してい る.だが，1902年にルールが今日のように【最 後にボールに触れたチームの相手チームがスロー インする】と改正されてから，このようなことは なくなった。また，この改正前の一時期，コート の外周を金網などで囲ってしまい，コート外のボ ール争奪戦が観客席に及ばないようにしたときも あった。ここからバスケットボールのゲームを “ケイジゲーム” (Cage game) と言い, プレイヤ 一のことを ‘ケイジャー’ (Cager) と呼ぶよう になった。この表現が今日なお使われているのは 興味深い。また，この『5秒ルール』も今日ほほ そのまま使用されている。

第10条 副審はプレイヤーを審判し，ファウ ルを記録し，連続3回のファウルがあった場合は 主審にこれを知らせる．主審は第 5 条によってプ レイヤーを失格させる権限を有する.

第11条 主審はプレイを判定し，いつボール がインプレイとなるか, インバウンズになるか, どちら側のチームにボールが与えられるのかなど を決定し，競技時間を計測する．また，ゴール成 功を確認し，その数も数える. このほかに，他の (種目の) ゲームで主審が通常おこなっているよ うな任務も務める.

ネイスミスはこのように当初から主審, 副審の 役割・任務を定めていた. しかし，当時のガード (のポジション）のプレイヤーはバスケット近辺 にいる副審からは遠く離れた位置でプレイするこ とが多かったので，副審の目が行き届かずファウ ルと判定されることが少なかった. そこで, 主塞, 副審の役割の見直しがおこなわれ，両審判が一体 となってプレイもプレイヤーも判定するようにな った。

第 12 条 競技時間は15分ハーフとし，間に5 分間のハーフタイムを置く.

今日，バスケットボールはあらゆる対象レベ ル—ミニ, 中学校, 高校, 大学, 男女プロなど一 に普及しているので，競技時間は一様ではない。 近年のルール変更は競技時間が長くなる傾向にあ 
る。国際ルールではピリオド制となり，1ピリオ ド 10 分, 第 $1-2$ ピリオドの間, 第 $3-4$ ピリオ ドの間に 2 分間のインターバルを設け，さらに第 $2-3$ ピリオドの間に 10 分もしくは15分間の八 ーフタイムが置かれている. 以前は 20 分ハーフ 制で，ハーフタイムは10分間であった。また， ミニでは 1 ピリオド 6 分，ハーフタイムを 5 分間 とし，各ピリオドの間は 1 分間のインターバルが 置かれている。このように競技時間は対象レベル によって異なり，多様化している.

第13条 ゴール成功が多かったほうのチーム が勝者となる. もし，同点の場合はキャプテンの 同意のもとに, つぎのゴールが成功するまでゲー ムを続ける.

ネイスミスは「バスケットボールはプレイヤー が主体的に取り組むべきものであって，コーチに よって左右されるものではない」と考えていたの で，キャプテンを高く位置づけていた。 ネイスミ スの願いのひとつは「バスケットボールを通じた プレイヤーのモラルの向上」であった．だから， プレイヤーに意志決定の選択肢を与えれば与える ほど，プレイヤーの人間的な成長により寄与する という信念を抱いていた。だから，延長戦の継続 の是非を話し合わせることもその一環であるとい う気持ちがあった（水谷，1980）。

\section{II誕生までの経緯}

さて，ネイスミスがバスケットボールを創案す るに至った経緯の発端を顧みておかねばならな い。このことについて，彼はつぎのように述べて いる（水谷, 1980).

1891 年の夏，国際YMCA トレーニングス クールに全米各州の YMCAの体育担当ス夕 ッフを集めて, 夏期講習 (Summer School) がおこなわれた。このとき，受講者は異口同 音に「冬季のとくに体育館でおこなう体育活 動の会員たちは体操中心の内容にはもはやま ったく関心を示さなくなっている」と各地の YMCAの苦境を報告した。そして, 従来の 体操にとって代わる“新しい種目”の必要性
を訴えた.ともかく，冬季の体育館でおこな う種目として，いままでにない，なにか“新 しいゲーム”が絶対に必要であり，冬になる までにそれを準備しなければならないことは 不可避となった。

ところで, 1870 年代末ころのアメリカで は大学の学生たちが, とくに, 陸上競技とア メリカンフットボールの大学対抗戦を始める ほどになっており, 学生たちの人気種目とな った。他方，大学時代にスポーツを経験した 者が卒業後に就職して都市に住むようになり， 余㗇にスポーツをしょうと考えたのはもっと もなことだ。そこで，彼らはスポーツができ る“クラブ”を探した。当時は町のアスレテ イック・クラブ，サイクリング・クラブ， あ るいはYMCA ぐらいしかなかった。ところ が, このようなクラブは冬季に入ると, 競技 スポーツのような種目は用意されておらず, もっぱら旧来の体操ばかりであった.かつて, 大学で競技スポーツをやってきた会員たち が，いつしかそのクラブの中心的存在となっ ていった. そして, アメリカンフットボール の面白さと集団体操のそれを比較して，冬季 種目への露骨な不満を隠さなかった.つまり, 新しい世代の若者たちは旧来の体操一辺倒の 体育による身体の鍛鍊そのもよりは，むしろ， スポーツする喜びや楽しさを求めたのだ.

夏季講習に参加した全米の各YMCAの体 育担当スタッフたちはこのような状況につい て, 熱心に論議を交わした. しかし, 誰一人 として，この問題を解決する具体策を提案で きる者はいなかった.

この事態を重視した国際YMCA トレーニング スクールの体育部担当主事 (全米各地の YMCA に巣立っていく体育スタッフ）養成科の科長 L. H. ギューリックは同科の 5 人の教員とともに 即応した。（ネイスミスは1890年 9 月に同科に入 学, 翌年の 1891 年 6 月の卒業と同時に教員とし て登用されていた。）初め，スウェーデン体操・ ドイツ体操・フランス体操を対象に検討したが, 妙案は浮かばなかった。つまるところ，「面白く 
て，覚えるのも，プレイするのも簡単で，しかも 冬季に照明のついた屋内でできる“新しいゲーム” が必要である」という結論に達した.ネイスミス はこのときのギューリックとの話し合いをつぎの ように記述している（水谷，1980）.

ギューリック博士は染料や合成薬品のよう に，各種の物を合成して製造する化学物質の 場合を例に引いて，「冬季に屋内でおこなう “新しいゲーム”というのはあり得ないので はないか。もし，そう言われるものがあった としても，それはただ単に既存のゲームの諸 要素を合成したものに過ぎないのではない か」と述べた。それに対して，私（ネイスミ ス）は「もし，そうであるとすれば，私たち が求める “新しいゲーム”を作り出すことは 可能だと思う．既存のゲームの要素を取り出 し，それらを再合成することによって作り出 せるのではないか」と述べた。

国際 YMCA トレーニングスクールには体育部 担当主事養成科と一般事業担当主事（総務・会 館・宗教・会員などのYMCAにおける体育館以 外の部門の担当者）養成科の二つが設けられてい た. 秋季のアメリカンフットボールのシーズンが 終わるまで，両科の体育の授業は合併しておこな っていた。それが冬季になると体育館で別々にお こなわれ，体操を中心とした授業をおこなってい た.これに反発したのが一般事業担当主事養成科 の学生たちであった。 かつて大学時代にスポーツ を経験してきた者が多く，いまさら各種体操系の 活動によって身体を鍛え，体格・体力の向上を目 指す気持ちはなかったからである。だから，担当 者を変えてもクラスの反応は変わらなかった。辛 イスミスはこの状況をみて，つぎのように指摘し ている (Naismith, 1936).

担当者が問題ではなく，指導内容が適切で ないことが問題なのだ。あの一般事業担当主 事養成科のような，いわゆる“おとな”相手 の授業は身心の鍜錬を目的とするものではな くむしろ，レクリェーション的なもののほ うが適切なのだ。かつて，大学時代に大いに 発揮していた彼らの“遊戯本能（スポーツ・
ゲームへの欲求）に応えるようなものが向い ていると思われる。

万策尽き果て，立ち往生した教員たちを見 とどけたギューリックはネイスミスに白羽の 矢を立てた。固辞するネイスミスにまったく 耳を貸すことなく，「一般事業担当主事養成 科の担当」と「新しいゲームの考案」という 二つの懸案の解決を命じた。その結果，ネイ スミスの手によって，バスケットボールが生 み出された。

\section{III 誕生前後の背景}

ネイスミスは「冬季に屋内でプレイできる新し いボールゲーム」の案出に成功した後の翌年早々 に，全米各地のYMCAにも送付されている国際 YMCA トレーニングスクールの「彙報」(“The Triangle”）にバスケットボールのことをつぎの ように紹介した（Naismith，1892）。

本校は読者各位に「新しいボールゲーム」 を披露したい。このゲームは各YMCAで必ず や人気種目になる要素を備えていると思われ る.グラウンドの競技場でアメリカンフット ボールをプレイするときと同じ気分を体育館 で味わえるからだ。このゲームは（YMCA の）会員なら誰でもプレイできるし，運動量 も豊富だ。すなわち，ゲーム中に判断力，各 部位の筋肉の相互作用を要するので，オール ラウンドな効果を期待できる，各YMCAの チーム対抗戦も可能だ. 剛胆さ，その場その 場に応じた心の働きや動作の素早さがより優 れたチームが勝利するにちがいない...

あたかも，（体育館でもプレイできる当時の人 気種目のアメリカンフットボールに匹敵する）な にか“斬新な種目”を渴望していた全米各地の YMCA は一斉にバスケットボールに飛び付いた. 1892 年 4 月, ニューヨークのブルックリン YMCAのセントラル・ブランチ（分館）の体育 担当スタッフからつぎのような書簡がネイスミス に届いている（水谷, 1980).

私のYMCAでバスケットボールを会員た 
ちにやらせてみたところ，予想をはるかに上 回る “好反応”でした。その後間もなく，各 ブランチごとにチームが生まれ，「ニューヨ ークYMCAリーグ」を結成しました。もっ とも優れていたのは当然, 私の YMCAチー ムです．冬季種目から春季種目に変わっても なお他のブランチ YMCA と凌ぎを削り合っ ています。

しかしながら,この書簡が起点となって, 以後, バスケットボールが順風満帆に普及, 振興の途を たどったわけではなかった。その第1の理由は 「それまで体操系の活動ならば50-60人を一度 にこなせる．だが，バスケットボールはわずか 10 人そこそこでフロアを独占してしまう」こと であった．とりわけ，創設が古いYMCAほど， その “アレルギー症状”が顕著で, 体育担当ス夕 ッフは公然とバスケットボールの価值に疑問を呈 した。ネイスミスが第2の理由として，つぎのよ うなことを指摘している（水谷, 1980).

当時の体育担当スッタフの多くは体操中心 の活動内容の指導には慣れていたし, 優れて はいたが，バスケットボールのような競技ス ポーツの指導の経験が欠如していた。これが 多くのチームがゲーム中にラフプレイやスポ ーツマンシップに反する行為を繰り返す原因 となった.

そして，とうとう，フィラデルフィア YMCA のノース・ブランチのように体育館からバスケッ トボールを締め出してしまうところも出てきた (水谷，1980）.しかし，こういう傾向とは逆に， バスケットボールを徐々に容認していく傾向も増 えていった。 その理由をネイスミスがつぎのよう に分析している（水谷，1980）。

第一はYMCAにとって全米規模の盛り上 がりを見せるバスケットボール人気を無視で きない勢いとなってきたこと，第二はバスケ ットボールの基本的な骨組み（1)ボールはい かなる方向にパスしてもよい，(2)ボールを保 持したまま移動してはならない，(3)ブロッキ ング，タックリングなどの身体接触は禁止す る，(4)ゴールは頭上に水平に設置する，(5)ゲ
一ムの目的はボールを味方がキープして，相 手ゴールへのショットを入れ合う）がまった く斬新だったことだ。

また，これとは別に，つぎのような理由もあっ た (Bunn, 1941).

1891 年にL. H. ギューリックがネイスミス に“新しいゲーム”の考案を命じたとき，ネ イスミスの先見の明と誠実さによってこのバ スケットボールの隆盛が最初から確実に約束 されていたようなものだ。その第一の理由と 考えられるのが「屋内ゲーム」とすることを 念頭に置いていたことだ。第二のそれはきち んと原則をたて，プレイの“許容内容”を明 示していたことだ。

それはともかく，ネイスミスに“新しいゲーム” の考案を命じたL. H. ギューリックはつぎのよう な考えを抱いていたとされる（水谷，1980）。

1890 年代初頭の体育はほぼ独占的と言える ぐらいに「体操」一辺倒であった。それには 二つの流れがあった，一つは手具体操を特徴 とするドイッ体操であり，もう一つは自由な 身体のうごきが特徴となっているスウェーデ ン体操系のものであった. (当時) われわれ が「競技スポーツ」と呼んだ種目は極少で, ゲームをやるにもその術（すべ）がなかった。 ところが，ちょうど時を同じくして，大学ス ポーツ界の主流は「体操」から「競技スポー ッ」に変わりつつあった. それは1870年代か ら芽生えた大学スポーツの胎動の確実な歩み の結果でもあった。だが，(当時の）体育の “本流”にはなり得ていなかった。ところが, 秋季にアメリカンフットボールに打ち込んで いた者たちにとっては冬季の（体育館におけ る）種々の体操は退屈かつ，つまらない時間 の無䭾以外のなにものでもなかった。喻えて 言えば“食欲があるのに空腹な者”を満足さ せるにはまったくほど遠かったのだ。まして や，内面的には「言わずもがな」であった。 かくして, 大学時代にスポーツの楽しさをた っぷりと味わってきた者たちに残ったのは然 え切れない「苛だたしさ」だけだったのだ。 
誕生直後からのバスケットボールはあたかも “野火”のごとく広まっていったという。その経 路は国際 YMCA トレーニングスクールを出発点 とする全米津々浦々に及ぶ“YMCA ネットワー ク”であった. しかも，当時のYMCA は最先端 の社会的体育・スポーツ活動組織であったと言っ ても過言ではない. 加えて, バスケットボールを プレイできる体育館を備えていた。だから，しば らくはバスケットボールというのは“YMCAの 専用スポーツ”と思いこんでいる人々が多かった (Browne, 1941).

つまり，1891 年に“鮮烈なデビュー”を果た したバスケットボールはいわば「時代の要求」に まさに適合したスポーツであった.そればかりか, ネイスミスの意匠には「プレイすればする程, 観 戦すればする程, 益々引き込まれる」というスポ ーツの本質の要諦がじつに巧みに込められていた ことがわかる.

\section{IV 普及の概況}

バスケットボールが誕生してから 3 年後の 1894 年1月，ネイスミスが『バスケットボール入門』 と題して，つぎのようなことを書いている（Naismith, 1894).

各ポジション（フォワード，センター，バ ック）にプレイヤーを配置する前に，つぎの ことをよく説明しておかなくてはいけない. (1)ボールは片手，もしくは両手以外で保持し てはならない.

(2)ボールを保持している者はその場から他の 位置に移動してはならない。

(3)ボールを足で蹴ったり，拳（こぶし）で吒 いてはならない.

(4)（アメリカンフットボールでは許されてい る）タックリングやホールディングをしては ならない。

プレイヤーはゲーム中にこの 4 点を順守し なくてはならない.アメリカンフットボール よりも野球の経験者のほうがバスケットボー ルでは優秀なプレイヤーになるものと思われ
る.その理由はアメリカンフットボールでは 「ラフプレイ」(“力と力の激突”）に対する “備え”さえあれば通用し，逆に，野球をや っていたプレイヤーは「ラフプレイ」に対す る“備え”は不要だし，他のどんなゲームよ りも“当意即妙”が求められるバスケットボ ールのプレイに柔軟に適応できる素地を有し ているからだ。

人数が同じ二つのチームをポジション別に コート上に配置する.フォワードは相手チーム のバックに近いところに立たせる.そして,ボ ールを保持したらコート中央に位置する味方 センターにパスでつなぐ. ボールをキャッチ したセンターは投げるか, 平手で叨いてフォ ワードにつなぐ.プレイはセンターを経由して 展開していく．ボールがアウトオブバウンズ になったときは審判がゲーム再開を指示する.

走っていたプレイヤーが空中にあるボール をキャッチした後，その位置で直ちにストッ プしようと試みたが止まりきれず，思わず 2 一3歩動いてしまったときは審判が勘酌して 違反としないように判定する。また，ボール を保持しているプレイヤーがボールを取り返 そうとする相手から激しく迫られたとき，思 わず（片足を同じ地点に着けたまま）もう片 方の足を踏み変えてボールをキープしようと した場合も違反とはみなさない。ただし，初 めに同じ地点に着けていた足を動かして，他 の地点に移したときはファウルとなる.

このネイスミスの記述から 6 ケ余後の 1894 年 7 月に, 国際 YMCA トレーニングスクールの 体育部担当主事盖成科の教員の A.T. ハルステッ ドがこのようなことを記している（Halsted， 1894).

全米各地のどこの YMCA でも体育活動の 人気 (登録会員数) は指導担当者の人柄と能 力, その YMCAの所在地 (通う便利さ), 体 育館の設備・用器具の充実さ, そして, なに よりも指導内容の新鮮さと質の高さで決ま る.しかし，このようなことを満たしている としても，人気を維持していくためのいろい 
ろな課題のうち，もっとも重要な“決め手” は会員たちの「人間が本来もっている遊戯本 能」をいかに的確に摇さぶるかということで ある. 従来，この点ではYMCAが十分に会 員たちに応えていたとは言い難い。このよう な状況にあって，ただひとつ，最近のバスケ ットボールは“例外”と言えよう。

けれども，だからとて「まったく問題なし」 とするのは安直である。競争的要素を備えた 活動が取り入れられようと，いかに教育的な 体操が始められようと，どのような遊戯（簡 易ゲーム）が紹介されようと $\cdots$ ，やがて，そ の YMCAの会員たちにとどまることなく， 近隣の YMCA との友好試合を模索し始める. ホームチームは当然ビジティングチームに勝 とうとする，もちろん，これは望ましい一面 もある。なぜならば，正しく“対抗戦”が管 理運営されれば，会員たちの人気（彼らの気 持ちをYMCAにつなぎとめておく可能性） が下落するとは考えられないからだ。その YMCA ゙, 州内のYMCA ゙, 地区の YMCA で, あるいは数州の YMCA で結成し たさまざまな『バスケットボールリーグ』は YMCAにおける体育事業のなかでは体操や 陸上競技のライバルとなっている，と言うの は, 他の野球やアメリカンフットボールと同 じように将来性のある競技スポーツとして堪 えうるように思えるからだ。他に衰退してい くものがあっても, バスケットボールの人気 は定着していくように見えるからだ。また， 競技スポーツは観衆を惹きつける．ピリッと して，気合いが入っている競技スポーツに多 くの観衆がつめかけるのは当然のことだ.

ところが，このようにYMCAにおいてバ スケトボール活動が盛んになっていくと, 経 費の増大が伴う。チームは交通費が必要にな るし，観衆は観戦料を払うことになるし… とにかく，経費がかさむ，したがって，「金を どのようにして工面するのか?」という難問 に突き当たる．考えられるのはその YMCA が地元で根強く暮らしに溶け込んでおり, 新
規入会者が絶えないという状況がもっとも望 ましい“資金源”となろう.あるいは，しっか りしたマネジメントのもとで開催する「リー グ戦」への観衆の入場料収入も期待できよう. この記述における [YMCA］というバスケッ トボールの誕生 $\rightarrow$ 普及を担った組織についてのつ ぎのような指摘は参考になる（Johnson, 1979).

1880 - 1900 年の北米におけるYMCA の興 隆は「保守的伝統の後退」,「急速な健康志向 の高まり」，「束縛のない自由な信仰という意 識への変化」に負うところが大きい.人々の 「信仰の見直し気運」およびその「社会的分別」 が博愛主義に根ざしたいくつかの社会的改革 団体の創設に結びついた。なかでも YMCA （基督教青年会）はなによりもこの適例であ る.ただ，伝道的熱意という当初の動機から やがて宗教に関係のないヒューマニズムへと 次第に理念を変貌させていったのだが一.

今日, バスケットボール誕生の地となったアメ リカ・マサチューセッツ州スプリングフィールド への空路のゲイトウエイのひとつはハートフォー ド（コネティカット州）である. 乗り入れ航空各 社の案内に “Hartford/Springfield” と表示され ているほどのごく“隣町”である。このハートフ オードYMCAについて，つぎのような記述があ る (Allen, 1894).

ハートフォードYMCAにおける過去 2 年 の冬季バスケットボールリーグの結果は他の YMCAへの優れた「手本」となろう。当然, 初めからきちんと組織化されて始まったわけ ではない，気の合う仲間どうしで結成された いろいろなチームが思い思いに活動してい た。このYMCAは毎週土曜日の夜は公式な 活動が組まれていなかった。しかし， YMCAの本音は「施設の活用と収入の増加」 であったが, 建前としては「地域住民，それ も若い人々の土曜日の夜の来館を歓迎する」 としていた.ところが，この状況が契機とな った。すなわち，“長老的会員” や関心を持 った会員たちが話し合いを開き，バスケット ボールリーグの結成とリーグ戦の立ち上げが 
決まった。

体育館を使用するすべてのチームに構想が 説明され，賛同を得た。と同時に，館内にリ ーグ戦の大きな揭示が張り出された. 新聞社 にも案内が送られ，報道を約束してくれた。 体育館使用チームの総会をおこない, 組織化 と代表者の選定をおこなった。およそ70名 の出席のもと 5 名の代表キャプテンを選び, 組織が結成された。この過程で中心的役割を 担ったのが銀行員, 保険外交員, 高校生など であった。，三の異論もあったようだが， 話し合いはまとまった。

それから,「リーグ」加盟チームは名称, ユニフォームカラーを決めた．各チームの工 ニフォーム着用と費用負担は投票で決着がつ けられたささらに，5名の代表キャプテンの 集まりを実行委員会とすることも投票で決め た. 委員会がリーグ運営管理とゲームの日程 の作成にあたることとなった。

\section{おわりに}

初めに述べたように，バスケットボールは 1936 年のオリンピック・ベルリン大会から（男 子）公式競技種目に採用された。“創始国”のア メリカも出場することにし，1936年 4 月 3 日ー5 日に“全米総合選手権大会”を開催して，「代表 チームメンバーの選考」をおこなうことにした。 このとき, 大学から 5 チーム, 実業団・クラブ (AAU) から2チーム，それにYMCAから1チー ムの計 8チームが出場した. YMCAチームは 3 月 に開催された全米 YMCA 選手権大会の（優勝チ ームに資格問題が生じたので）準優勝のペンシル バニア州のウイルマーディング YMCA チームで あった（Bingham, 1936)。つまり，バスケット ボールがオリンピック種目になった頃のアメリカ のバスケットボール界ではYMCAもその主流の 一角を占めていたことがわかる。つまり，バスケ ットボールは文字通り“YMCA スポーッ”とし ての道程を歩んで発展してきた証左であろう。換 言するならば，全米各州各地に所在する無数の
YMCAというネットワークを通じて，いわばア メリカの社会・文化の源流をなす“グラスルーツ 人気”を得て，成長してきたことがわかる.

このように「バスケットボールの創成」を顧み ると，つぎのような指摘に辿り着かざるを得ない (Johnson, 1979).

アメリカのYMCA 史を顧みると，19世紀 末の 20 年間は画期的という表現がもっとも似 合う。希にみる衝撃性と活力が発露した“革 新と実験”の時期であった。 バスケットボー ルとバレーボールという “New game” の創 案はなによりもこのことを物語っている.

\section{文献}

Allen, W.L. (1894) BASKET BALL AT HARTFORD, CONN. Physical Education, 3-4. The Triangle Publishing Company: Springfield, MA, p 58.

Bingham, L.J. (1936) Report of The American Olympic Committee. American Olympic Committee: New York, pp. 165-172.

Browne, J. (1941) The Y.M.C.A. Originated Basketball and Carried It 'Round the World, Naismith Memorial Committee, Basketball Hall of Fame: Springfield, MA, p 12.

Bunn, J. (1941) The Value of Basketball. Naismith Memorial Committee, Basketball Hall of Fame: Springfield, MA, p 9.

Halsted, T.A. (1894) BASKET BALL, Physical Education, $3-5$. The Triangle Publishing Company: Springfield, MA, p 76.

Johnson, L.E. (1979) The History of YMCA Physical Education. Association Press (Follet Publishing Company): Chicago, IL, pp. 45-47.

水谷 豊訳 (1980) バスケットボール その起源と 発展. YMCA 出版：東京, pp. 37-116.

Naismith, J. (1892) BASKET BALL, The Triangle, 110. The Triangle Publishing Company: Springfield, MA, pp. 144-147.

Naismith, J. (1894) HOW TO START BASKET BALL, Physical Education, 11-11. The Triangle Publishing Company: Springfield, MA, pp. 179180.

Naismith, J. (1914) BASKET BALL, APER, 1-3. The American Physical Education Society: New York, pp. 339-340.

Wolff, A. (2002) The Olden Rules. Sports Illustrated, November: 118-125.

平成 16 年 9 月 7 日受付 平成 16 年 11 月 6 日受理 